\title{
Yield of Shallot as Affected by Nitrogen on Water Hyacinth Compost and Inorganic Fertilizer at Fluventic Eutrudepts
}

\author{
Hildy Levia Maranggi ${ }^{1, ~ *, ~ E m m a ~ T r i n u r a n i ~ S o f y a n ~}{ }^{1}$, Rija Sudirja ${ }^{1}$, Benny Joy ${ }^{1}$, Anni Yuniarti ${ }^{1}$, \\ Kusumiyati $^{2}$, Betty Natalie Fitriatin ${ }^{1}$ \\ ${ }^{1}$ Department of Soil Science, Faculty of Agriculture, University of Padjadjaran, Bandung, Indonesia \\ ${ }^{2}$ Department of Agronomy, Faculty of Agriculture, University of Padjadajran, Bandung, Indonesia
}

Email address:

hildyleviam@gmail.com (H. L. Maranggi)

${ }^{*}$ Corresponding author

\section{To cite this article:}

Hildy Levia Maranggi, Emma Trinurani Sofyan, Rija Sudirja, Benny Joy Anni Yuniarti, Kusumiyati, Betty Natali Fitriatin. Yield of Shallot as Affected by Nitrogen on Water Hyacinth Compost and Inorganic Fertilizer at Fluventic Eutrudepts. International Journal of Natural Resource Ecology and Management. Vol. 5, No. 4, 2020, pp. 139-144. doi: 10.11648/j.ijnrem.20200504.11

Received: September 27, 2020; Accepted: October 12, 2020; Published: October 16, 2020

\begin{abstract}
Fluventic Eutrudepts is widely distributed in Indonesia but has low fertility to be used for agricultural activity. Soil nutrition availability could be enhancing by fertilization. The objective of this research was to determine the effect of water hyacinth compost and N, P, K, S fertilizer dosage on nitrogen rate in soil and plant, so quantity and quality in shallot. The experiment was held from March until June 2020 at Soil Chemistry, and Plant Nutrition Experimental Field, Agriculture Faculty, Universitas Padjadjaran, Jatinangor, Sumedang, at an altitude about $\pm 745 \mathrm{~m}$ above sea levels. This research used experiment method with Randomized Block Design, had seven treatments and four replications. The treatments were: control, 1 dosage of N, P, K, S fertilizer recommendation, the dosage of N, P, K, S fertilizer $(1,3 / 4)$; and dosage of water hyacinth compost $\left(1 / 2,1,1 \frac{1}{2}\right)$. The result of this experiment showed that water hyacinth compost and $\mathrm{N}, \mathrm{P}, \mathrm{K}, \mathrm{S}$ fertilizer dosage significantly affected on nitrogen rate in soil and crops, quantity and quality of shallots. The combination of $1 / 2$ dosage of water hyacinth compost and $3 / 4$ dosage of $N, P, K, S$ fertilizer effectively gave a better effect than other treatments.
\end{abstract}

Keywords: Shallot Yield, Nitrogen, Water Hyacinth Compost, Inorganic Fertilizer

\section{Introduction}

Shallot is one of several horticulture commodities that had high economic value. So, it could contributes to regional economic development. Based on monthly production data, this commodity showed a fluctuating result that repeated every year. In 2012, shallot production reached $964.221 \mathrm{t}$, but it had not reached daily public needs [4]. Usually, in AprilJune import level increases due to low yield gain because of the last rainy season. Batu Ijo is one of several shallot varieties that had wide-adapt potency that it could grow and produce in both low and highland. Bulbs production of this variety could reach $18,5 \mathrm{t} / \mathrm{ha}$ dried bulbs [3]. In addition to the utilization of superior varieties, shallot yield could be enhancing by land extensification with utilization of marginal area.

Fluventic Eutrudepts is one of another subgroup of
Inceptisols. Inceptisols are occupying $37,5 \%$ or 70,52 bi ha of Indonesia land area and widely distributed around Sumatera, Papua, Maluku, Sulawesi, Kalimantan, West Nusa Tenggara, Bali, and Java [15]. However, Inceptisols has low fertility to be used as agricultural land. Especially, in Fluventic Eutrudepts, organic matter and nutrient as nitrogen, phosphor, potassium, and sulfur were classified as low [13]. This causes plant growth resisted so soil productivity needs to improve by fertilization. Fertilization is adding one or more available nutrients to maintain soil fertility and enhance crop yield [1].

Inorganic fertilizer more common used by farmers because it released nutrients in an available form so plant root could absorb it directly. Besides that, the addition of nutrients could increase soil fertility. Nitrogen, phosphor, potassium, and sulfur are four macro essentials to support shallot growth. Nitrogen $(\mathrm{N})$ could be found from Urea in nitrate $\left(\mathrm{NO}_{3}{ }^{-}\right)$form, $\mathrm{SP}-36$ for phosphor in $\mathrm{PO}_{2}^{-}, \mathrm{HPO}_{2}^{-}, \mathrm{H}_{2} \mathrm{PO}_{4}{ }^{2-}$ form, $\mathrm{KCl}$ for potassium $(\mathrm{K})$ in $\mathrm{K}^{+}$, and 
$\mathrm{ZA}$ that contains sulfur in $\mathrm{SO}_{4}{ }^{2-}$ and nitrogen in ammonium $\left(\mathrm{NH}_{4}{ }^{+}\right)$form. In addition to that, inorganic fertilizer usage continuously could damage soil fertility.

Nitrogen was important to support shallots growth because it concluded into short-life crop. Nitrogen was absorbed by plant through mass flow in $\mathrm{NO}_{3}{ }^{-}$form and $\mathrm{NH}_{4}{ }^{+}$absorbed through root interception and difusion. Nitrogen was constituented material of protein, nucleac acid, nucleoprotein, and alkaliod. Nitrogen deficiency would obstruct cell enlargement and plant growth would not maximized. Urea and ZA was some fertilizers that contain nitrogen. Beside that, plant biomass like water hyacinth also contain nitrogen, so it can enhanced nitrogen rate on soil. Not every compounds could be absorbed by plant, some of thembecame residue, leached in soil, or evaporated [7].

A combination of organic and inorganic fertilizer could maintain soil fertility. Organic compounds contain nutrients and could revitalized soil physic properties. Compost is one type of organic fertilizer that produced from the decomposition process. Water hyacinth was known as a troublesome weed and cause as negative impact on its environment. Usage of a water-based plant, water hyacinth, as an organic matter resource did to prevent expansive growth on its environment. In this experiment, this plant contains high enough chemical composition to be used as crop nutrients supply, which is $1,57 \%$ nitrogen, $0,50 \%$ phosphor, $2,50 \%$ potassium, 35,95 ppm sulfur, $40 \%$ organic carbon, and $\mathrm{C} / \mathrm{N} 25$. A combination of inorganic and organic fertilizer became necessary in the fertilization efficiency concept on shallot cultivation. This is important because we need to produced shallot in good quality in fulfilling shallots demand through fertilization technology and maintain soil health. So that, utilization of inorganic and organic fertilizer through this experiment intended to maintain soil health and gained shallots yield in good quality.

\section{Materials and Methods}

\subsection{Experimental Site}

The experiment was conducted in the net house of Experimental Field Soil Chemical and Plant Nutrition Laboratory, Faculty of Agriculture, UNPAD, in the altitude of \pm 745 meters above sea level. The experiment was done from February to August 2020. Climate condition on-site had an average temperature, $23,4^{\circ} \mathrm{C}$, from February until July 2020 , rainfall intensity about $267,75 \mathrm{~mm}$ per month, and had humidity around $85-90 \%$. The classification of soil in this experiment was Inceptisols, great group Eutrudepts, subgroup Fluventic Eutrudepts which taken from The Experimental Field of Soil Chemical and Plant Nutrition Laboratory. Nutrients status before experiment are: quite low $\mathrm{pH}(6,48)$, very low-middle rate nutrient content $(\mathrm{N}$-total $0,19 \%, \mathrm{P}_{2} \mathrm{O}_{5} 58,28 \mathrm{mg} / 100 \mathrm{~g}, \mathrm{~K}_{2} \mathrm{O} 31,54 \mathrm{mg} / 100 \mathrm{~g}$, and $\mathrm{SO}_{4}{ }^{2-}$ $5,11 \mathrm{ppm})$, middle CEC $(21,96 \mathrm{cmol} / \mathrm{kg})$, low organic carbon $(1,83 \%)$, and low-middle exchangeable cation.

The tools used in this experiment were; shovel, hoe, tape measure, bucket, and laboratory equipment. The materials were; Inceptiols in subgroup Fluventic Eutrudepts, shallot tubers of Batu Ijo varieties, water hyacinth compost originated from a pond, bioactivator (contains functional bacteria, Trichoderma harzianum, and Cytophaga sp.) Urea for nitrogen $(\mathrm{N})$ source, SP-36 for phosphor $(\mathrm{P}), \mathrm{KCl}$ for potassium $(\mathrm{K})$, and ZA for nitrogen $(\mathrm{N})$ and sulfur $(\mathrm{S})$. Urea and ZA applied on 7 DAS and 21 DAS meanwhile, SP-36 and $\mathrm{KCl}$ carried out when planting time. The dosage of fertilizer used as Petrokimia Gresik (2011) recommendations

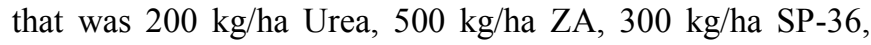
$200 \mathrm{~kg} / \mathrm{ha} \mathrm{KCl}$, and 25t/ha water hyacinth compost.

\subsection{Experimental Design}

This research was conducted by experiment methods and employing randomized block design (RBD). The treatment of the experiment included five combinations of inorganic and organic fertilizer dosage, one inorganic fertilizer recommendation dosage, and one treatment as a control for comparison. Every treatment was repeated four times and build in two units and with the result of that, a total of polybags are 56. Treatments were; control; N, P, K, S recommendation dosage; $3 / 4$ dosage $\mathrm{N}, \mathrm{P}, \mathrm{K}, \mathrm{S} ; 1 / 2$ Compost + $3 / 4$ dosage N, P, K, S, Kompos + 3/4 dosage N, P, K, S, 11/2 compost $+3 / 4$ dosage $\mathrm{N}, \mathrm{P}, \mathrm{K}, \mathrm{S}$, and compost $+\mathrm{N}, \mathrm{P}, \mathrm{K}, \mathrm{S}$. The observed parameters were nitrogen rate on soil and crops (Kjeldahl Method), yield component that were; number of bulbs, bulbs diameter, fresh bulbs weight, and dry bulbs weight.

The first step in this researched was took soil sample to analyzed and got information about soil condition before the experiment was carried out. Soil sampling was done by composite sampling then prepared them before took them to laboratory. Water hyacinth decomosition started by cutting it into small pieces so microorganism and bioactivator could worked optimally to speed up water hyacinth biomass decomposition. Decomposition processed was done in anaerobic condition. Compost was ready applied on media when had temperature below $30^{\circ} \mathrm{C}$, colored, and smelled like soil or around four weeks. Crop maintenance was done by sprinkling and pest controlling. Shallot for consumption harvested in 50-55 DAP (day after plant) and had characteristics such as, its leaves weakened while the stem was hardened, its leaves turned yellow $70-80 \%$ of total plants, and the tubers came out on the surface. Its bulb colored purpleish dark red. After that, shallot bulbs dried in room temperature for 10 days to got dried bulbs weight.

\subsection{Statistical Data Evaluation}

Data analyses were conducted by SPSS ver. 16 and Duncan's Multiple Range Test (DMRT) at the level of 5\% to detect the differences among treatments if showed a significant effect.

\section{Results and Discussion}

\subsection{Nitrogen Rate on Soil and Crops}

In this experiment, $\mathrm{N}$ was obtained from water hyacinth 
compost and Urea, so ZA. Nitrogen availability depends on the fixation and denitrification process. Nitrogen obtained by crops from organic and inorganic matter in nitrate $\left(\mathrm{NO}_{3}{ }^{-}\right)$and ammonium $\left(\mathrm{NH}_{4}{ }^{+}\right)$form. The result of soil analysis before the experiment was held, showed soil $\mathrm{N}$-total content was $0,19 \%$ which classified as a low category. Figures 1 and 2 below, showed the alteration of $\mathrm{N}$ concentrate on soil and crop.

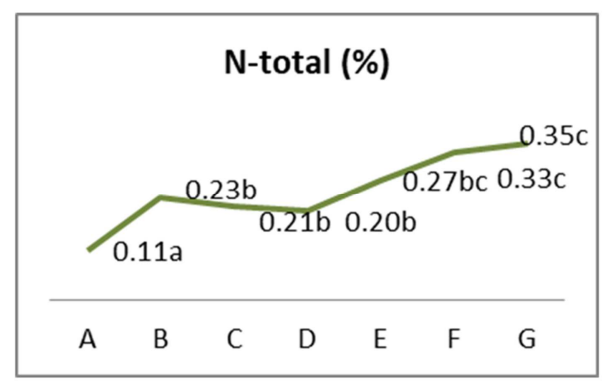

Figure 1. Effect of Water Hyacinth Compost and N, P, K, S Fertilizer on soil $N$-total.

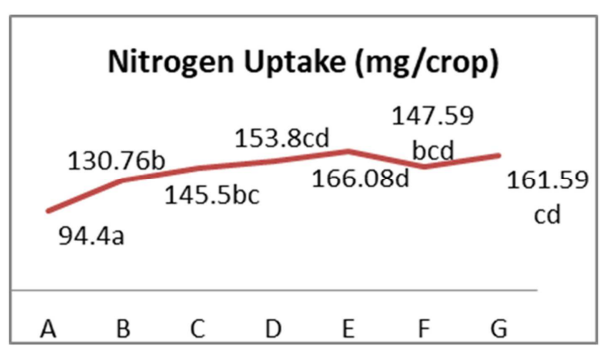

Figure 2. Effect of Water Hyacinth Compost and N, P, K, S Fertilizer on N uptake of shallot.

Figure 1 showed soil $\mathrm{N}$ concentration in every treatment had given. Based on Figure 1, we can see that every treatment had a significantly different on $\mathrm{N}$-total of soil with control. Both of water hyacinth compost or inorganic fertilizer from Urea and ZA that were used in this experiment contain 1,68\% $\mathrm{N}$ from $30 \mathrm{~kg}$ fresh biomass, $46 \% \mathrm{~N} / \mathrm{kg}$, and $21 \% \mathrm{~N} / \mathrm{kg}$ and released into the soil and raised $\mathrm{N}$ content compared to without fertilizer treatment. Compost $+3 / 4$ dosage $\mathrm{N}, \mathrm{P}, \mathrm{K}, \mathrm{S} ; 1 \frac{1}{2}$ compost $+3 / 4$ dosage $\mathrm{N}, \mathrm{P}, \mathrm{K}, \mathrm{S}$; and compost $+\mathrm{N}, \mathrm{P}, \mathrm{K}, \mathrm{S}$ gave the most differently significant. That could happen by $\mathrm{N}$ losses in soil because of run-off on the surface, evaporation, leaching, and absorb by crops was prevented by the application of organic matter.

Organic matter could hold water and nutrients so prevented them from leached easily. The amount of organic matter in soil determines soil capability to provided $\mathrm{N}$ nutrient that was produced from the decomposition of biomass [17]. Furthermore, organic matter could increase soil cation exchange capacity (CEC) so $\mathrm{N}$ exchange on cation and anion form would be increased [9].

With the result of that, combination of water hyacinth compost and N, P, K, S fertilizer was better to raised soil Ntotal beside a single $\mathrm{N}, \mathrm{P}, \mathrm{K}, \mathrm{S}$ fertilizer application. Compost $+\mathrm{N}, \mathrm{P}, \mathrm{K}, \mathrm{S}$ treatment showed the highest rate and the most significantly different than other treatment on soil N-total rate. This is due to the amount of $\mathrm{N}$ input in this treatment was the highest compared to other treatments. According to [6] statement, the higher of $\mathrm{N}$ fertilizer application, the higher $\mathrm{N}$-total rate in soil, because more of $\mathrm{N}$ accumulated in soil. So in this experiment, compost $+\mathrm{N}, \mathrm{P}, \mathrm{K}, \mathrm{S}$ could increase the highest soil $\mathrm{N}$-total compared with other treatments. However, compost $+3 / 4$ dosage N, P, K, S treatment showed no significant effect with compost $+\mathrm{N}, \mathrm{P}$, $\mathrm{K}$, S treatment on soil N-total rate. So, that treatment is an efficient treatment to increase soil N-total.

Nitrogen uptake of shallot gained from $\mathrm{N}$ concentrate in crop multiplied with dry crop weight. Soil N-total rate and $\mathrm{N}$ mineralization affected $\mathrm{N}$ uptake in plant tissue. The result of Duncan's Multiple Range Test (DMRT) of 5\% level (Figure 2) showed that the combination of water hyacinth compost and N, P, K, S fertilizer shows a significantly different effect on $\mathrm{N}$ uptake of shallot. Every combination of water hyacinth compost and N, P, K, S fertilizer treatments showed higher $\mathrm{N}$ uptake rate compared with single $\mathrm{N}, \mathrm{P}, \mathrm{K}, \mathrm{S}$ fertilizer. Water hyacinth biomass contributed $\mathrm{N}$ nutrient and increase soil capability to provided $\mathrm{N}$ for crop. Enhancement of soil $\mathrm{N}$ concentrate would increase $\mathrm{N}$ which absorbed on plant tissue [10]. Compost $+3 / 4$ dosage N, P, K, S treatment showed the highest $\mathrm{N}$ uptake compared other combination treatments. The most effective treatment in increase ability of plant to absorb $\mathrm{N}$ in soil was $1 / 2$ compost $+3 / 4$ dosage $\mathrm{N}, \mathrm{P}, \mathrm{K}, \mathrm{S}$, because this treatment didn't show any difference with other combination treatments even with minimum input.

\subsection{Shallot Yield}

Yield components that observed in this experiment were; total of bulbs, bulbs diameter, fresh bulbs weight, and dry bulbs weight.

\subsubsection{Number of Bulbs}

The result of the statistical test showed that application of water hyacinth compost and $\mathrm{N}, \mathrm{P}, \mathrm{K}, \mathrm{S}$ fertilizer had a significant effect on number of bulbs as presented in Table 1 below. Control produced four bulbs and the highest treatment which produced nine bulbs was compost $+3 / 4$ dosage $N, P, K$, S. Addition of N, P, K, S recommendation and $3 / 4$ dosage N, P, $\mathrm{K}$, S didn't show a significant effect, but combination of compost and $3 / 4$ dosage of $N, P, K, S$ gave a significant effect on produced more bulbs compared to $\mathrm{N}, \mathrm{P}, \mathrm{K}, \mathrm{S}$ recommendation treatment.

Table 1. Effect Application of Water Hyacinth Compost and N, P, K, S Fertilizer on Number of Bulbs.

\begin{tabular}{ll}
\hline Treatment & Number of Bulbs \\
\hline A) Control & $4 \mathrm{a}$ \\
B) N, P, K, S recommendation & $7 \mathrm{~b}$ \\
C) $3 / 4$ dosage N, P, K, S & $8 \mathrm{bc}$ \\
D) $1 / 2$ compost + 3/4 dosage N, P, K, S & $8 \mathrm{bc}$ \\
E) Compost $+3 / 4$ dosage N, P, K, S & $9 \mathrm{c}$ \\
F) $1 \frac{1}{2}$ compost $+3 / 4$ dosage N, P, K, S & $8 \mathrm{bc}$ \\
G) Compost $+\mathrm{N}, \mathrm{P}, \mathrm{K}, \mathrm{S}$ & $8 \mathrm{bc}$ \\
\hline
\end{tabular}

Note: Letters of a, b, and c explain the different significance. The number as followed by the same letter in each column is not significantly different according to Duncan's Multiple Range Test at 5\% probability level. 
Some factors which influenced number of bulbs were varieties and nutrients availability. As one type of varieties, the characteristic of Batu Ijo was produced 2-5 bulbs. Based on table above, control produced the same as Batu Ijo characteristic which produced four bulbs. While other treatments that adding fertilizer produced more bulbs which showed nutrients availability affected total of bulbs. Nitrogen has a role on photosynthetic rate, and enhances the synthesis of protein that used in cell forming so optimized plant growth in vegetative stage [16].

That condition would enhance sprout number per plant and gained more total of bulbs when harvesting [5]. Nitrogen could increase total of bulbs because amino acid, protein, and cell protoplasm were the component of vegetative that could stimulate tuber forming [8]. Beside $\mathrm{N}$, organic matter repaired soil physic with forming soil aggregate, revitalized soil permeability and aeration so plant roots could penetrate deeper and wider. It will affect plant to producing total of bulbs because plant could stand firm and be able to absorb nutrients in an optimal state [11].

\subsubsection{Diameter of Bulbs}

Bulbs diameter measured with calipers during the harvesting period. Application of water hyacinth compost and N, P, K, S fertilizer didn't show any significant effect to shallots bulbs diameter as represented in Table 2. Bulbs on control had a bigger diameter size than other treatments. Meanwhile, the smallest diameter contained on $1 \frac{1}{2}$ compost $+3 / 4$ dosage N, P, K, S treatment. The diameter of bulbs that produced relate with number of bulbs produced. Refers to Table 1, the fewer total of bulbs that had been produced, the larger diameter of bulbs will be. It can be influenced by effect of $\mathrm{N}$ that applied on planting media stimulate vegetative organ growth. So, it causes form much more sprout if $\mathrm{N}$ applied in high dosage and produced more tuber. The more of total of bulbs created, photosynthate produced by photosynthesis will divide into bulbs were created. If there was less tuber, every tuber would absorbed more photosynthate and induced bigger shallot bulbs diameter.

Table 2. Effect Application of Water Hyacinth Compost and N, P, K, S Fertilizer on Diameter of Bulbs.

\begin{tabular}{ll}
\hline Treatment & Diameter of Bulbs \\
\hline A) Control & 2,53 a \\
B) N, P, K, S recommendation & 2,02 a \\
C) $3 / 4$ dosage N, P, K, S & 2,11 a \\
D) $1 / 2$ compost + 3/4 dosage N, P, K, S & 2,09 a \\
E) Compost $+3 / 4$ dosage N, P, K, S & 2,16 a \\
F) $1 \frac{1}{2}$ compost $+3 / 4$ dosage N, P, K, S & 1,98 a \\
G) Compost + N, P, K, S & 2,24 a \\
\hline
\end{tabular}

Note: The number as followed by the same letter in each column is not significantly different according to Duncan's Multiple Range Test at 5\% probability level

Aside from nitrogen, diameter of bulbs affected by potassium. This element could synthesize protein from ammonium and enhance metabolism process inside crop to formed perfect bulbs. Potassium escalated translocation of photosynthesis output from leaf to plant reproductive organs tissue through phloem. According to the result [2] experiment, the addition of $\mathrm{K}$ fertilizer with $120 \mathrm{~kg} \mathrm{~K}_{2} \mathrm{O} \mathrm{ha}^{-1}$ combined with compost increase the number of shallot bulbs diameter. So, it indicates $\mathrm{K}$ has a role in optimizing plant photosynthesis activity. So that photosynthate accumulation could be translocated to generative part of shallot.

\subsubsection{Fresh Bulbs Weight}

The application of water hyacinth compost and inorganic fertilizer showed a significant effect on fresh bulbs weight as presented on Table 3. Control got the lowest fresh bulbs weight that is $74,10 \mathrm{~g}$. Although this treatment produced the biggest bulbs diameter size, control had fewer bulbs than other treatments. Nitrogen was important on spurred plant vegetative growth so affected shallot yield in fresh bulbs or dry shelf-life weight [12]. Addition if nutrients will optimize height growth and total of leaf so maximize the photosystesis process. Based on the research, utilization of $\mathrm{N}$ fertilizer from Urea, ZA, and foliar fertilizer showed a significant effect on enhanced shallot fresh bulbs weight per plot and per ha. Nitrogen availability necessary in plant growth process because it became protein composer and nucleic acid molecule in chlorophyll molecule so $\mathrm{N}$ could influence the photosynthesis process. Fulfillment of $\mathrm{N}$ needs would strengthen plant growth and utilization of nutrients efficiently to increase plant productivity.

Table 3. Effect Application of Water Hyacinth Compost and N, P, K, S Fertilizer on Shallots Fresh Bulbs Weight.

\begin{tabular}{ll}
\hline Treatment & Fresh Bulbs Weight \\
\hline A) Control & $2,53 \mathrm{a}$ \\
B) N, P, K, S recommendation & $2,02 \mathrm{a}$ \\
C) $3 / 4$ dosage N, P, K, S & $2,11 \mathrm{a}$ \\
D) $1 / 2$ compost $+3 / 4$ dosage N, P, K, S & $2,09 \mathrm{a}$ \\
E) Compost $+3 / 4$ dosage N, P, K, S & $2,16 \mathrm{a}$ \\
F) $1 \frac{1}{2}$ compost $+3 / 4$ dosage N, P, K, S & $1,98 \mathrm{a}$ \\
G) Compost $+\mathrm{N}, \mathrm{P}, \mathrm{K}, \mathrm{S}$ & $2,24 \mathrm{a}$ \\
\hline
\end{tabular}

Note: Letters of a, b, and c explain the different significance. The number as followed by the same letter in each column is not significantly different according to Duncan's Multiple Range Test at 5\% probability level.

$1 \frac{1}{2}$ compost $+3 / 4$ dosage $N, P, K, S$ and compost $+N, P, K$, $\mathrm{S}$ showed differently significant with control but not different with $\mathrm{N}, \mathrm{P}, \mathrm{K}, \mathrm{S}$ recommendation and $3 / 4$ dosage N, P, K, S. $1 / 2$ compost $+3 / 4$ dosage $\mathrm{N}, \mathrm{P}, \mathrm{K}, \mathrm{S}$ and compost $+3 / 4$ dosage $\mathrm{N}$, $\mathrm{P}, \mathrm{K}, \mathrm{S}$ were treatments that had the most differently significant with control. The smallest difference founded in $\mathrm{N}, \mathrm{P}, \mathrm{K}, \mathrm{S}$ recommendation with control, that is $21,09 \mathrm{~g}$. Meanwhile, the biggest difference founded in compost $+3 / 4$ dosage $\mathrm{N}, \mathrm{P}, \mathrm{K}, \mathrm{S}$ that is $43,31 \mathrm{~g}$. So based on this research compost $+3 / 4$ dosage $\mathrm{N}, \mathrm{P}, \mathrm{K}, \mathrm{S}$ produced 117,41 $\mathrm{g}$ fresh bulbs weight, the highest fresh bulbs weight compared to other treatments. Nevertheless, $1 / 2$ compost $+3 / 4$ dosage N, P, $\mathrm{K}, \mathrm{S}$ was more effective because had not different effect with compost $+3 / 4$ dosage $\mathrm{N}, \mathrm{P}, \mathrm{K}$, and produced $113,24 \mathrm{~g}$ fresh bulbs weight.

\subsubsection{Dry Bulbs Weight}

The result of DMRT showed that application of water 
hyacinth compost and N, P, K, S fertilizer had a significant effect on dry weight of shallot.

Table 4. Effect Application of Water Hyacinth Compost and N, P, K, S Fertilizer on Shallots Dry Bulbs Weight.

\begin{tabular}{ll}
\hline Treatment & Dry Bulbs Weight \\
\hline A) Control & 2,53 a \\
B) N, P, K, S recommendation & 2,02 a \\
C) $3 / 4$ dosage N, P, K, S & 2,11 a \\
D) $1 / 2$ compost $+3 / 4$ dosage N, P, K, S & 2,09 a \\
E) Compost $+3 / 4$ dosage N, P, K, S & 2,16 a \\
F) $1 \frac{1}{2}$ compost $+3 / 4$ dosage N, P, K, S & 1,98 a \\
G) Compost $+\mathrm{N}, \mathrm{P}, \mathrm{K}, \mathrm{S}$ & $2,24 \mathrm{a}$ \\
\hline
\end{tabular}

Note: Letters of $a, b$, and $c$ explain the different significance. The number as followed by the same letter in each column is not significantly different according to Duncan's Multiple Range Test at $5 \%$ probability level.

As presented in Table 4, control gave the lowest dry bulbs weight that was $45,53 \mathrm{~g}$ in the polybag and $9,10 \mathrm{t}$ as converted in 1 ha. $\mathrm{N}, \mathrm{P}, \mathrm{K}, \mathrm{S}$ recommendation and $3 / 4$ dosage $\mathrm{N}, \mathrm{P}, \mathrm{K}, \mathrm{S}$ produced dry bulbs weight higher than control, but lower than treatments that had combination of compost and N, P, K, S fertilizer. According to [10], the addition of titonia bokashi affected on shallots dry bulbs weight. Nitrogen keeps vegetative organs getting bigger so do plant biomass weight.

As the table above, combination of compost and N, P, K, S fertilizer that produced the highest dry bulbs weight was compost $+3 / 4$ dosage $\mathrm{N}, \mathrm{P}, \mathrm{K}, \mathrm{S}$. In polybag this treatment produced $89,38 \mathrm{~g}$ or $17,87 \mathrm{t} / \mathrm{ha}$. The most effective to induced dry bulbs weight was $1 / 2$ compost $+3 / 4$ dosage $\mathrm{N}, \mathrm{P}, \mathrm{K}, \mathrm{S}$ because not showed any different effect with treatments that gave the highest dry bulbs weight. The enhanced dry bulbs weight was affected by soil capability to provide $\mathrm{N}$ to be absorbed by plant. Enhancement of dry bulbs weight related to $\mathrm{N}$-uptake because it was indicated plant capability to absorb $\mathrm{N}$ on air and soil would give a positive impact on plant growth [14]. Aside from inorganic fertilizer, organic fertilizer could contribute nutrients like $\mathrm{N}$ from plant biomass. Organic matter also had an important role in increased microorganism activity to transform organic $\mathrm{N}$ into inorganic $\mathrm{N}$ [17]. With the result of that, combination of compost and N, P, K, S fertilizer could generate shallots dry bulbs weight better than control and utilization of $\mathrm{N}, \mathrm{P}, \mathrm{K}, \mathrm{S}$ fertilizer only.

\section{Conclusions}

1. Utilization of water hyacinth could prevented waters pollution and contain nutrient that useful to enhanced plant growth.

2. Nitrogen on water hyacinth compost and N, P, K, S fertilizer affect yield of shallot (Allium ascalonicum L.) on Fluventic Eutrudepts.

3. $1 / 2$ compost $+3 / 4$ dosage $\mathrm{N}, \mathrm{P}, \mathrm{K}, \mathrm{S}$ which had $12,5 \mathrm{t} / \mathrm{ha}$ water hyacinth compost, $150 \mathrm{~kg} / \mathrm{ha}$ Urea, $225 \mathrm{~kg} / \mathrm{ha} \mathrm{SP}$ $36,150 \mathrm{~kg} / \mathrm{ha} \mathrm{KCl}$, and $37, \mathrm{~kg} / \mathrm{ha} \mathrm{ZA}$ showed as the most effective treatment to enhanced yield of shallot on Fluventic Eutrudepts.

\section{Acknowledgements}

This research was funded by Soil Chemistry and Plant Nutrition Laboratory, Faculty of Agriculture, University of Padjadjaran.

\section{References}

[1] Agriculture Training Center (2015). Fertilization. Association of Instructure Agent and Agriculture Development.

[2] Alfian, D. F., Nelvia, and H. Yetti (2015). The effect of potassium fertilizer and oil palm empty bunches with boiler ash on shallots growth and yield. Jurnal Agroteknologi, Vol. 5, No. 2, page: 1-6.

[3] Balitsa (2018). Varieties of Shallot: Batu Ijo. East Java.

[4] Basuki, R. S. (2014). Identification of problem and shallots farming analysis in highland on rainy season at Majalengka. Balitsa. Journal of Horticulture, Vol. 24, No. 3, page: 266-275.

[5] Elisabeth, D. W., Santoso, M., and Herlina, N (2013). Effect of addition various organic matter composition on shallots growth and yield. Plant Production Journal, Vol. 1, No. 3.

[6] Firmansyah, I., and Sumarni (2013). Effect of nitrogen fertilizer dosages and varieties on soil $\mathrm{pH}$, soil $\mathrm{N}$-total, $\mathrm{N}$ uptake, and shallots yield in entisols brebes. Journal of Horticulture, Vol. 4, No. 23, page: 358-364.

[7] Hilman, Y., Gina, A., and Liferdi, L (2014). Nitrogen effect on production, nutrients uptake, and nitrogen-use efficiency of shallot (Alliun cepa var. Aggeratum). AAB Bioflux, Vol. 6, No. 2, page: $128-133$.

[8] Irawan D, Idwar, and Murniati (2017). Effect of N, P, K fertilizer in varieties of shallots yield in ultisols. Online Journal of Agriculture Faculty, Univrsity of Riau, Vol. 4, No. 1, page: $1-14$.

[9] Mulyani, N. S., M. E. Suryadi, S. Dwiningsih, and Haryanto (2001). Dynamics of nitrogen on paddy field. Journal of Soil and Climate, No. 19, page: 14-25.

[10] Putra, C. R., I. Wahyudi, and U. Hasanah (2015). Nitrogen uptake and shallots production because addition of titonia bokashi in entisols guntarano. E-Jurnal Agrotechnobis, Vol. 3, No. 4, page: $448-454$.

[11] Ramadhan, A. F. N., and Titin S (2018). The response of shallot (Allium ascalonicum L.) to manure and inorganic fertilizer. Plant Production Journal, Vol. 6, No. 5, page: 815-822.

[12] Romdoni, A., Suwarto, A. Maharihaya, and T. S. Yuliani (2019), Effect of inorganic fertilizer replacement with manure on shallots growth, production, and shelf-life. Journal of Agronomy, Vol. 47, No. 3, page: 283-290.

[13] Sandrawati, A, E. T. Sofyan, O. Mulyani (2007), Effect of kitchen-waste compost and cow manure on soil chemical characteristics and maize yield (Zea mays Saccharata Sturt.) in Fluventic Eutrudepts Jatinangor. Research Report. University of Padjajaran.

[14] Sofyan, E. T., D. S. Sara, and Y. Machfud (2019). The effect of organic and inorganic fertilizer applications on N, P-uptake, $\mathrm{K}$-uptake and yield of sweet corn (Zea mays saccharata Sturt). IOP Conf. Series: Earth and Enviromental Science 393. 
[15] Soil and Agroclimate Research Center (2006). Acidic soil in indonesia, Inceptisols. Bogor.

[16] Supriyatna, S. Salman, and D. R. Nugraha (2016). Combination of liquid organic fertilizer, compost, and inorganic fertilizer on shallots (Allium ascalonicum L.) growth and yield. Journal of Agricultural Sciences and Veterinary, Vol. 4, No. 1, page: 103-113.
[17] Wijanarko, A., Benito, H. P., Dja'far, S., and Didik, I (2012). The effent of organic matter quality and soi fertility on nitrogen mineralization and nitrogen uptake by cassava in ultisol. Plantation and Tropical Land Journal, Vol. 2, No. 2. 